Jews in the Notarial Culture 


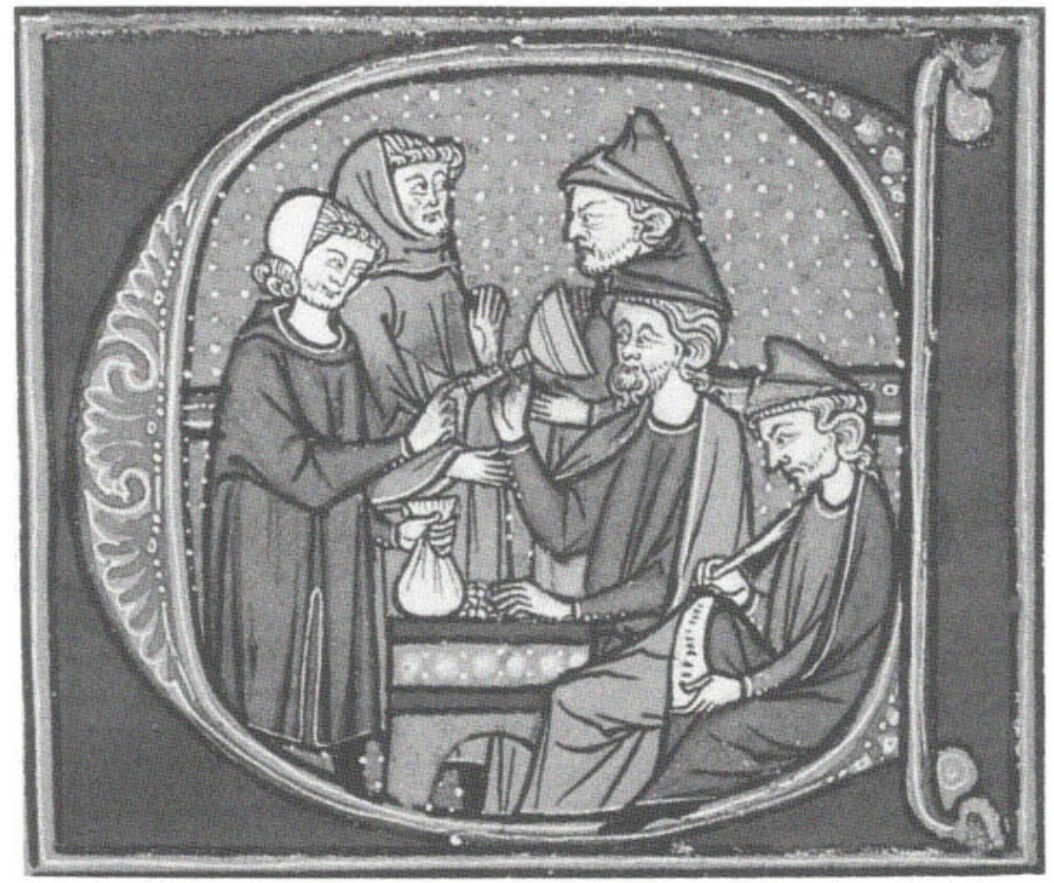

In this letter E, two Jewish merchants sell a gilded goblet to two Christians. A third Jew acts as notary for the transaction, a rare depiction of the soffer. For a contract between persons of differing religio-ethnic backgrounds, the notary or scribe must be of the same religion as the seller or promiser. Detail from In Excelsis Dei Thesauris (Feudal Customs of Aragon), Called "Vidal Mayor," folio 114 r, compiled between 1247 and 1252 by Vidal de Canellas for King Jaume the Conquerer, of Aragon. Collection of the J. Paul Getty Museum, Los Angeles, California. 


\section{Jews in the Notarial Culture}

Latinate Wills in

Mediterranean Spain,

$1250-1350$

Robert I. Burns, S.J. 
University of California Press

Berkeley and Los Angeles, California

University of California Press

London, England

Copyright $(\mathcal{O} 1996$ by The Regents of the University of California

Library of Congress Cataloging-in-Publication Data

Burns, Robert Ignatius.

Jews in the notarial culture : Latinate wills in Mediterranean Spain, 1250-1350 / Robert I. Burns.

p. $\mathrm{cm}$.

Includes bibliographical references and index.

ISBN 0-520-20393-3 (alk. paper)

1. Wills-Spain-Aragon-History. 2. Jews-Legal status, law's, etc.-Spain-Aragon-History. 3. Law, Medieval. 4. Wills (Jewish law) I. Title.

KKT5341.64.B87 1996

$346.46^{\prime} 55054^{\prime} 08992-\mathrm{dc} 20$

[344.6550654089924]

Printed in the United States of America

\section{9}

The paper used in this publication meets the minimum requirements of American National Standard for Information Sciences-Permanence of Paper for Printed Library Materials, ANSI Z39.48-1984@ 